2016

\title{
Caddo Ceramic Vessels from Lake Sam Rayburn Sites
}

Timothy K. Perttula

Heritage Research Center, Stephen F. Austin State University

Mark Walters

Heritage Research Center, Stephen F. Austin State University

Follow this and additional works at: https://scholarworks.sfasu.edu/ita

Part of the American Material Culture Commons, Archaeological Anthropology Commons, Environmental Studies Commons, Other American Studies Commons, Other Arts and Humanities Commons, Other History of Art, Architecture, and Archaeology Commons, and the United States History Commons

Tell us how this article helped you.

This Article is brought to you for free and open access by the Center for Regional Heritage Research at SFA ScholarWorks. It has been accepted for inclusion in Index of Texas Archaeology: Open Access Gray Literature from the Lone Star State by an authorized editor of SFA ScholarWorks. For more information, please contact cdsscholarworks@sfasu.edu. 


\section{Caddo Ceramic Vessels from Lake Sam Rayburn Sites}

Creative Commons License

(c) (i) @ (9)

This work is licensed under a Creative Commons Attribution-NonCommercial 4.0 International License 


\section{Caddo Ceramic Vessels from Lake Sam Rayburn Sites}

\section{Timothy K. Perttula and Mark Walters}

\section{INTRODUCTION}

The distinctive Caddo ceramic vessels from the lower Neches-Angelina (i.e., Lake Sam Rayburn, see Jelks 1965) (Figure 1) and the lower Sabine (i.e., Toledo Bend Reservoir, see McClurkan et al. 1966; Woodall 1969) river basins are not well understood, due to current cultural phase taxonomic difficulties and poorly defined ceramic assemblages. Sites in these areas were included in the Angelina focus by Jelks (1965), which was a "broadly defined unit encompassing the entire Caddoan [sic] sequence in the Lake Sam Rayburn locality; needs reevaluation in light of larger sample of sites which are known in the area" (Story 1990:Table 43). Perttula (1992:253) used the term late Angelina focus to refer to sites in these localities that date after ca. A.D. 1400, but this taxonomic terminology is also not satisfactory. The vessels from the Lake Sam Rayburn Caddo sites warrant restudy, because currently it is difficult to determine what a representative assemblage of ceramic fine ware and utility ware vessels from this part of the Neches-Angelina River basin looks like, and the differing affiliations of local Caddo groups.

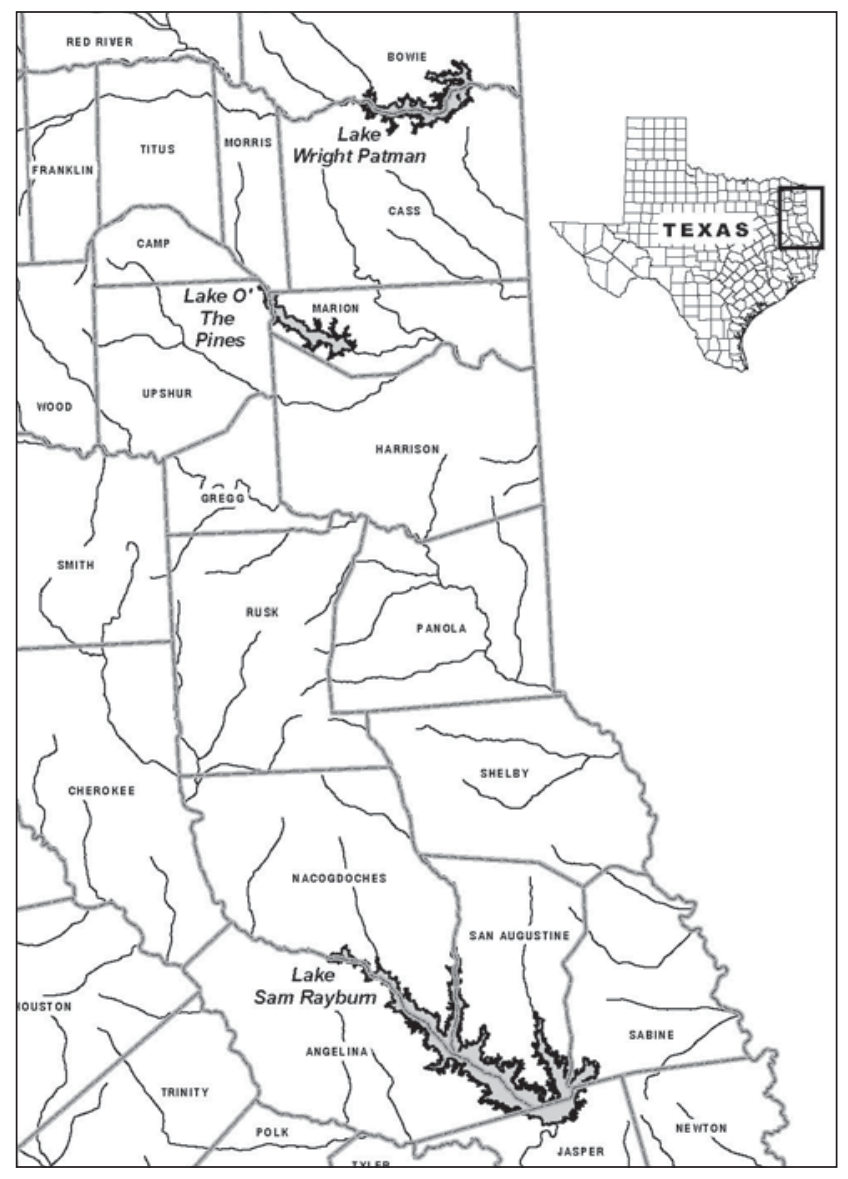

Figure 1. The location of Lake Sam Rayburn in East Texas. 
Few of the vessels recovered from burials at Lake Sam Rayburn have been typologically identified. The rarity of Belcher Ridged sherds in the Lake Sam Rayburn sites when compared to their frequency in Toledo Bend Reservoir sites appears to indicate that the ancestral Caddo groups that once occupied these two areas had distinctly different utility ware traditions. Furthermore, stylistically-related Titus phase and Belcher phase engraved fine wares are absent in the Lake Sam Rayburn sites, much different from the Toledo Bend Reservoir ceramic assemblages (see Perttula and Selden 2014:Tables 2 and 3; Perttula and Walters 2015), a trend which may be indicative of differing populations of Caddo peoples living in these two locales. The Lake Sam Rayburn ceramic assemblages warrant a thorough reanalysis - paired with radiocarbon dates from organics (and organic residues on sherds and vessels) in the collections - before it will be possible to establish their temporal, stylistic, and compositional character and diversity, and explore their relationship to other ancestral Caddo ceramic traditions in East Texas and Northwest Louisiana. This article summarizes the reanalysis of the Lake Sam Rayburn ceramic vessels.

There are 21 vessels in the Texas Archeological Research Laboratory, The University of Texas at Austin collections from Lake Sam Rayburn archaeological investigations. This includes: 12 vessels from Walter Bell (41SB50); one vessel from Bird Point Islands (41SB71); one vessel from the Sawmill site (41SA89); six vessels from the Wylie Price site (41SA94); and one vessel from the Blount site (41SA123).

\section{Walter Bell Site (41SB50)}

The Walter Bell site was excavated by an NPS team in 1957 (Jelks 1965:53-69). This was a small prehistoric Caddo farmstead or hamlet with two circular houses, a portion of a third house in the area of House 2, midden deposits, and six burials (Figure 2). Based on the kinds of artifacts found at the site (i.e., clay elbow pipes, a high proportion of brushed utility ware sherds from Broaddus Brushed vessels, and lower proportions of Pineland Punctated-Incised vessel sherds), the Walter Bell site was apparently occupied after ca. A.D. 1450-1500, in the Late Caddo period and the Late Angelina phase (see Middlebrook 1994:26-29 and Figure 4, 1997; Perttula et al. 2009:22).

Four of the burials (Burials 1-3 and 6) were in close association (either inside the house and underneath the house floor) with House 1, one (Burial 4) was inside House 2, and Burial 5 was in an open area, possibly a courtyard or work area between the two Caddo houses. Funerary offerings placed with the deceased included ceramic vessels, Perdiz arrow points, conch shell beads, deer ulna tools and deer food offerings, mussel shells, and engraved bird bone flageolets.

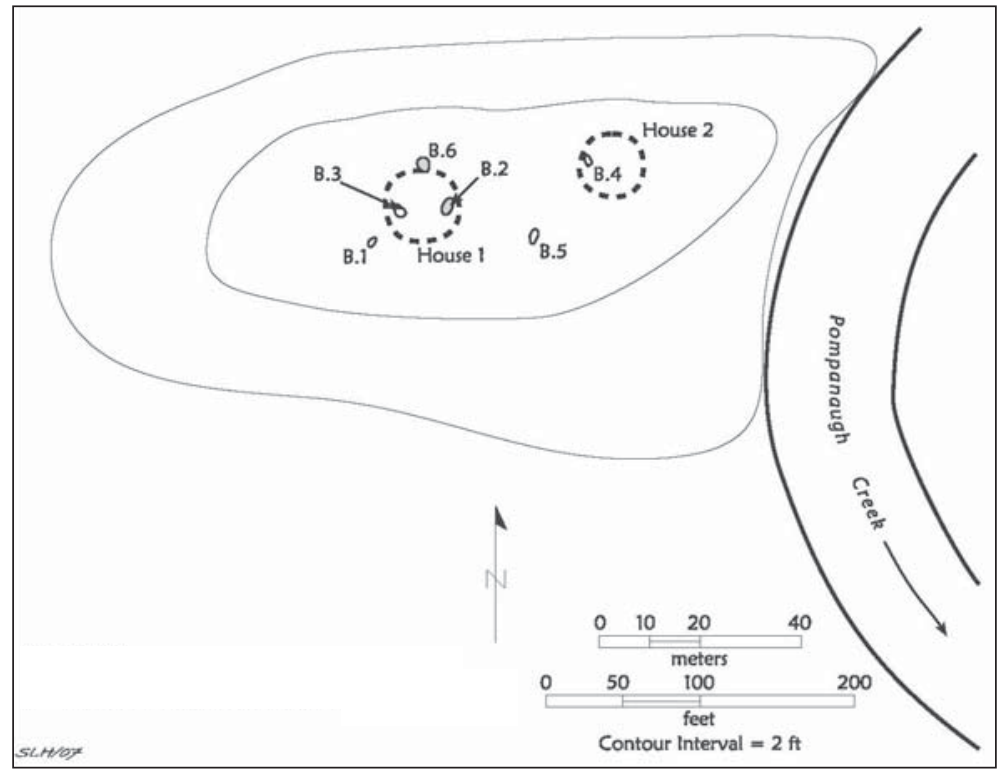

Figure 2. Map of the Walter Bell site and the locations of Houses 1 and 2 and Burials 1-6. 


\section{Vessels}

There are 12 vessels in the TARL collections from the Walter Bell site. Eleven of the vessels are from the excavations led by Jelks (1965), and the other is a vessel donated by George M. Fern.

SITE NAME OR SITE NUMBER: Walter Bell (41SB50)

VESSEL NO.: 2

VESSEL FORM: Jar with four rim peaks

NON-PLASTICS AND PASTE: grog

RIM AND LIP FORM: Everted rim and rounded lip

CORE COLOR: B (fired and cooled in a reducing environment)

INTERIOR SURFACE COLOR: very dark grayish-brown

EXTERIOR SURFACE COLOR: very dark grayish-brown; fire clouds on the body

WALL THICKNESS (IN MM): rim, $7.2 \mathrm{~mm}$

INTERIOR SURFACE TREATMENT: smoothed

EXTERIOR SURFACE TREATMENT: none

HEIGHT (IN CM): 14.0

ORIFICE DIAMETER (IN CM): 11.4

DIAMETER AT BOTTOM OF RIM OR NECK (IN CM): 10.4

BASE DIAMETER (IN CM) AND SHAPE OF BASE: 7.6; circular and flat

ESTIMATED VOLUME (IN LITERS): 1.0

DECORATION (INCLUDING MOTIF AND ELEMENTS WHEN APPARENT): There are three rows of tool punctates on the vessel rim. The vessel body has diagonal brushing marks that extend to the vessel base.

PIGMENT USE AND LOCATION ON VESSEL: none

TYPE AND VARIETY (IF KNOWN): Unidentified utility ware

SITE NAME OR SITE NUMBER: Walter Bell (41SB50)

VESSEL NO.: 954

VESSEL FORM: Jar

NON-PLASTICS AND PASTE: grog 
RIM AND LIP FORM: Direct rim and rounded lip

CORE COLOR: F (fired in a reducing environment and cooled in the open air)

INTERIOR SURFACE COLOR: dark grayish-brown; fire clouds on the rim

EXTERIOR SURFACE COLOR: yellowish-brown; fire clouds on the rim, body, and base

WALL THICKNESS (IN MM): rim, $4.0 \mathrm{~mm}$

INTERIOR SURFACE TREATMENT: smoothed

EXTERIOR SURFACE TREATMENT: none

HEIGHT (IN CM): 6.4

ORIFICE DIAMETER (IN CM): 7.2

DIAMETER AT BOTTOM OF RIM OR NECK (IN CM): 7.0

BASE DIAMETER (IN CM) AND SHAPE OF BASE: 5.1; circular and flat

ESTIMATED VOLUME (IN LITERS): 0.27

DECORATION (INCLUDING MOTIF AND ELEMENTS WHEN APPARENT): The rim is decorated with horizontal brushing marks. The vessel body has a continuous series of vertical incised lines that extend from the rim to $0.9 \mathrm{~cm}$ of the base.

PIGMENT USE AND LOCATION ON VESSEL: none

TYPE AND VARIETY (IF KNOWN): Unidentified utility ware

SITE NAME OR SITE NUMBER: Walter Bell (41SB50)

VESSEL NO.: 956, Burial 3

VESSEL FORM: Carinated bowl

NON-PLASTICS AND PASTE: bone

RIM AND LIP FORM: Inverted rim and rounded, exterior folded lip

CORE COLOR: $\mathrm{G}$ (fired in a reducing environment and cooled in the open air)

INTERIOR SURFACE COLOR: grayish-brown

EXTERIOR SURFACE COLOR: reddish-brown

WALL THICKNESS (IN MM): rim, 5.6 mm

INTERIOR SURFACE TREATMENT: smoothed 
EXTERIOR SURFACE TREATMENT: burnished

HEIGHT (IN CM): 7.5

ORIFICE DIAMETER (IN CM): 15.8

DIAMETER AT BOTTOM OF RIM OR NECK (IN CM): 17.8

BASE DIAMETER (IN CM) AND SHAPE OF BASE: 8.9; circular and rounded

ESTIMATED VOLUME (IN LITERS): 0.70

DECORATION (INCLUDING MOTIF AND ELEMENTS WHEN APPARENT): The rim panel has a horizontal engraved scroll motif repeated six times around the vessel (Figure 3). Each scroll is defined by excised brackets that extend between two horizontal engraved lines. Between the brackets is a single horizontal to curvilinear engraved line. Finally, the upper horizontal engraved line that connects the brackets ends in a small excised pendant triangle.

PIGMENT USE AND LOCATION ON VESSEL: none

TYPE AND VARIETY (IF KNOWN): Glassell Engraved



Figure 3. Decorative elements on Glassell Engraved carinated bowl (No. 956) from Burial 3 at the Walter Bell site (41SB50).

SITE NAME OR SITE NUMBER: Walter Bell (41SB50)

VESSEL NO.: 957, Burial 3

VESSEL FORM: Jar

NON-PLASTICS AND PASTE: bone

RIM AND LIP FORM: Everted rim and a rounded, exterior folded lip; the vessel has a very short rim

CORE COLOR: F (fired in a reducing environment and cooled in the open air)

INTERIOR SURFACE COLOR: yellowish-brown; fire clouds on the base

EXTERIOR SURFACE COLOR: yellowish-brown; fire clouds on the rim and body

WALL THICKNESS (IN MM): rim, $5.4 \mathrm{~mm}$

INTERIOR SURFACE TREATMENT: none 
EXTERIOR SURFACE TREATMENT: none

HEIGHT (IN CM): 6.6

ORIFICE DIAMETER (IN CM): 7.6

DIAMETER AT BOTTOM OF RIM OR NECK (IN CM): 7.7

BASE DIAMETER (IN CM) AND SHAPE OF BASE: 3.7; circular and flat

ESTIMATED VOLUME (IN LITERS): 0.30

DECORATION (INCLUDING MOTIF AND ELEMENTS WHEN APPARENT): The vessel rim and body are decorated with vertical to diagonal brushing marks.

PIGMENT USE AND LOCATION ON VESSEL: none

TYPE AND VARIETY (IF KNOWN): cf. Karnack Brushed-Incised (see Suhm and Jelks 1962:Plate 43)

SITE NAME OR SITE NUMBER: Walter Bell (41SB50)

VESSEL NO.: 958, Burial 3

VESSEL FORM: Jar

NON-PLASTICS AND PASTE: grog

RIM AND LIP FORM: Direct rim and a rounded lip

CORE COLOR: B (fired and cooled in a reducing environment)

INTERIOR SURFACE COLOR: black

EXTERIOR SURFACE COLOR: black

WALL THICKNESS (IN MM): rim, $6.6 \mathrm{~mm}$

INTERIOR SURFACE TREATMENT: smoothed

EXTERIOR SURFACE TREATMENT: none

HEIGHT (IN CM): 10.7

ORIFICE DIAMETER (IN CM): 11.5

DIAMETER AT BOTTOM OF RIM OR NECK (IN CM): 11.5

BASE DIAMETER (IN CM) AND SHAPE OF BASE: 6.4; circular and flat

ESTIMATED VOLUME (IN LITERS): 0.74 
DECORATION (INCLUDING MOTIF AND ELEMENTS WHEN APPARENT): The principal decorative element on the vessel rim is an incised triangle filled with tool punctations; there are two upper and lower incised triangles around the vessel rim (Figure 4). Between the incised triangles are areas filled with diagonal brushing marks that are overlain with diagonal incised lines pitched in opposite directions.

PIGMENT USE AND LOCATION ON VESSEL: none

TYPE AND VARIETY (IF KNOWN): Unidentified utility ware

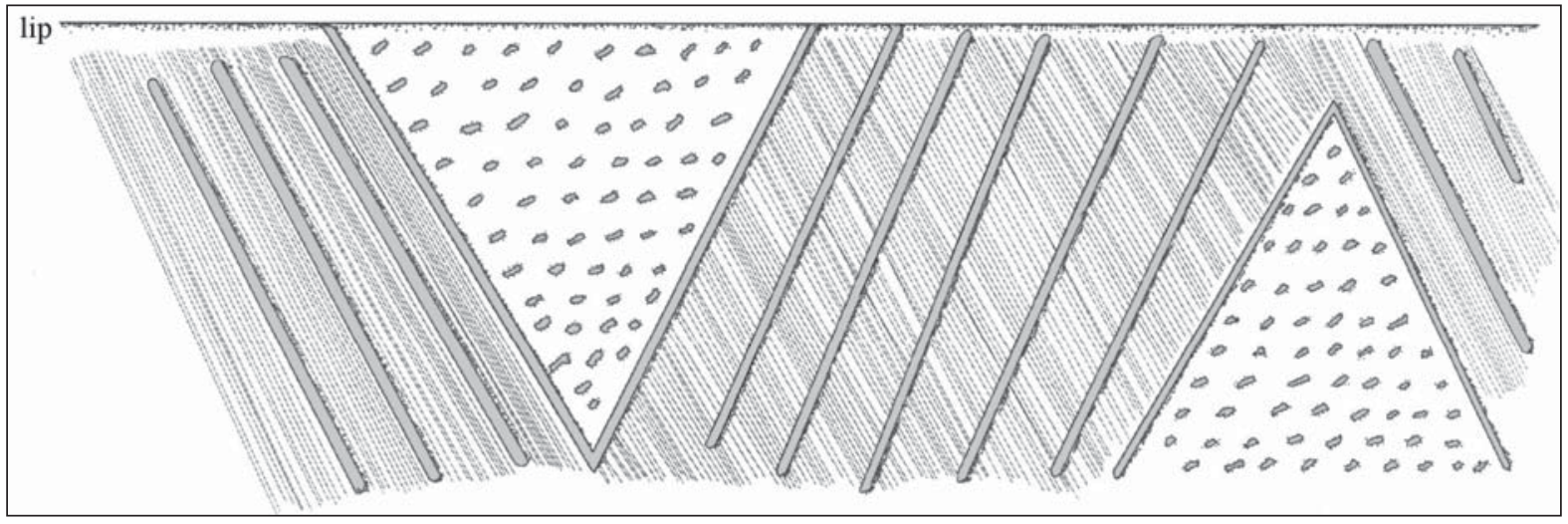

Figure 4. Decorative elements on incised-punctated-brushed jar (No. 958) from Burial 3 at the Walter Bell site (41SB50).

SITE NAME OR SITE NUMBER: Walter Bell (41SB50)

VESSEL NO.: 959

VESSEL FORM: Jar

NON-PLASTICS AND PASTE: grog

RIM AND LIP FORM: Direct rim and rounded, exterior folded lip

CORE COLOR: B (fired and cooled in a reducing environment)

INTERIOR SURFACE COLOR: black

EXTERIOR SURFACE COLOR: black; exterior organic residue on the vessel body

WALL THICKNESS (IN MM): rim, $6.5 \mathrm{~mm}$

INTERIOR SURFACE TREATMENT: smoothed

EXTERIOR SURFACE TREATMENT: none

HEIGHT (IN CM): 15.8

ORIFICE DIAMETER (IN CM): 12.3

DIAMETER AT BOTTOM OF RIM OR NECK (IN CM): 11.3 
BASE DIAMETER (IN CM) AND SHAPE OF BASE: 7.0; circular and flat ESTIMATED VOLUME (IN LITERS): 1.2

DECORATION (INCLUDING MOTIF AND ELEMENTS WHEN APPARENT): There are a continuous series of vertical incised lines that cover the entire vessel from the rim to the vessel base.

PIGMENT USE AND LOCATION ON VESSEL: none

TYPE AND VARIETY (IF KNOWN): Unidentified utility ware, cf. Belcher Ridged

SITE NAME OR SITE NUMBER: Walter Bell (41SB50)

VESSEL NO.: 960, Burial 3

VESSEL FORM: Carinated bowl

NON-PLASTICS AND PASTE: grog

RIM AND LIP FORM: Direct rim and rounded, exterior folded lip

CORE COLOR: B (fired and cooled in a reducing environment)

INTERIOR SURFACE COLOR: black

EXTERIOR SURFACE COLOR: black

WALL THICKNESS (IN MM): rim, $5.9 \mathrm{~mm}$

INTERIOR SURFACE TREATMENT: smoothed on the rim

EXTERIOR SURFACE TREATMENT: smoothed

HEIGHT (IN CM): 7.8

ORIFICE DIAMETER (IN CM): 19.5

DIAMETER AT BOTTOM OF RIM OR NECK (IN CM): 18.0

BASE DIAMETER (IN CM) AND SHAPE OF BASE: 8.5; circular and flat

ESTIMATED VOLUME (IN LITERS): 0.92

DECORATION (INCLUDING MOTIF AND ELEMENTS WHEN APPARENT): Plain

PIGMENT USE AND LOCATION ON VESSEL: none

TYPE AND VARIETY (IF KNOWN): Unidentified plain ware 
SITE NAME OR SITE NUMBER: Walter Bell (41SB50)

VESSEL NO.: 1001, Burial 5

VESSEL FORM: Carinated bowl

NON-PLASTICS AND PASTE: grog

RIM AND LIP FORM: Direct rim and rounded, exterior folded lip

CORE COLOR: B (fired and cooled in a reducing environment)

INTERIOR SURFACE COLOR: grayish-brown

EXTERIOR SURFACE COLOR: grayish-brown; fire clouds on the rim

WALL THICKNESS (IN MM): rim, 5.6 mm

INTERIOR SURFACE

TREATMENT: smoothed

EXTERIOR SURFACE

TREATMENT: none

HEIGHT (IN CM): 8.5

ORIFICE DIAMETER

(IN CM): 13.8

DIAMETER AT

BOTTOM OF RIM OR

NECK (IN CM): 12.2

BASE DIAMETER (IN CM) AND SHAPE OF

BASE: 5.5; circular and flat

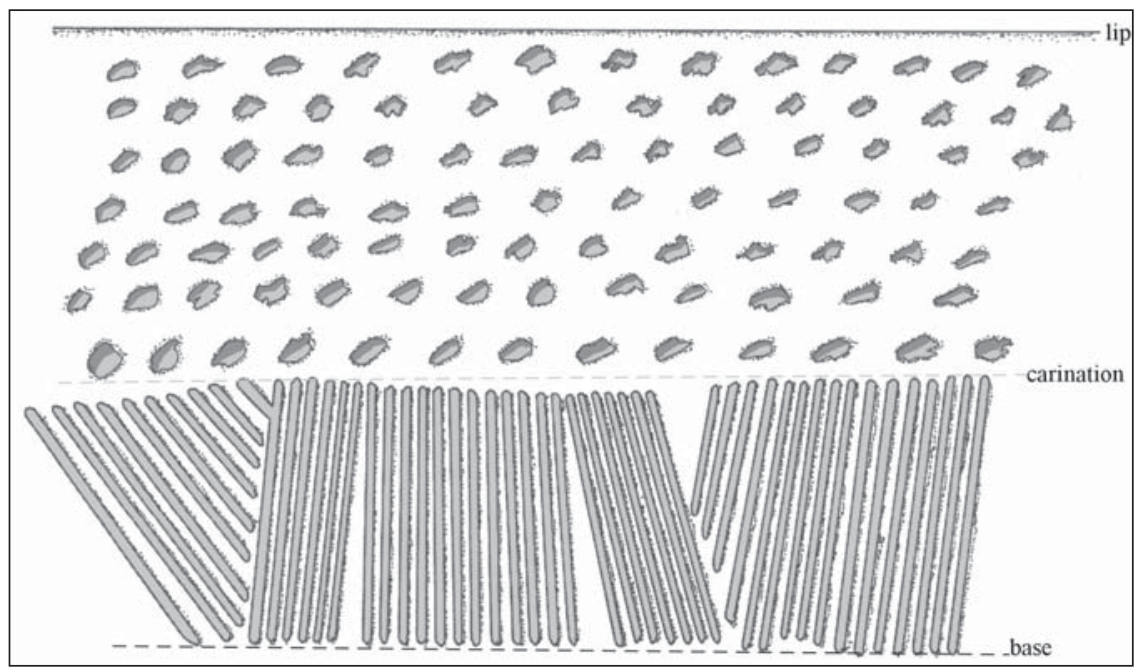

Figure 5. Punctated-incised carinated bowl (No. 1001) from Burial 5 at the Walter Bell site (41SB50).

ESTIMATED VOLUME (IN LITERS): 0.71

DECORATION (INCLUDING MOTIF AND ELEMENTS WHEN APPARENT): The rim panel is filled with seven or more rows of closely-spaced tool punctations. The vessel body has sets of finely incised vertical or diagonal opposed incised lines that extend to the vessel base (Figure 5).

PIGMENT USE AND LOCATION ON VESSEL: none

TYPE AND VARIETY (IF KNOWN): Unidentified utility ware 
SITE NAME OR SITE NUMBER: Walter Bell (41SB50)

VESSEL NO.: 1002

VESSEL FORM: Bottle with a short neck

NON-PLASTICS AND PASTE: grog

RIM AND LIP FORM: Everted rim and rounded lip

CORE COLOR: $\mathrm{G}$ (fired in a reducing environment and cooled in the open air)

INTERIOR SURFACE COLOR: reddish-brown

EXTERIOR SURFACE COLOR: grayish-brown; fire clouds on the neck, body, and the base

WALL THICKNESS (IN

MM): rim, $6.6 \mathrm{~mm}$

INTERIOR SURFACE

TREATMENT: none

EXTERIOR SURFACE

TREATMENT: smoothed

HEIGHT (IN CM): 17.6

ORIFICE DIAMETER (IN

CM): 5.8

DIAMETER AT

BOTTOM OF RIM OR

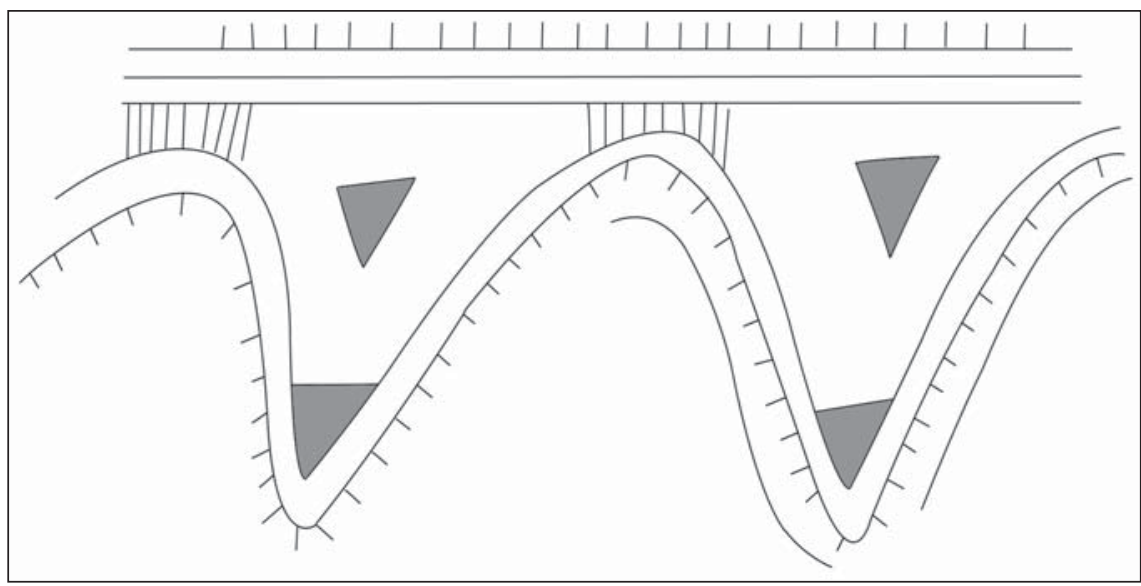

Figure 6. Engraved bottle (No. 1002) from the Walter Bell site (41SB50).

NECK (IN CM): 6.9; maximum

body diameter of $14.2 \mathrm{~cm}$

BASE DIAMETER (IN CM) AND SHAPE OF BASE: 8.5; circular and flat

ESTIMATED VOLUME (IN LITERS): 0.60

DECORATION (INCLUDING MOTIF AND ELEMENTS WHEN APPARENT): There are three horizontal engraved lines below the neck-body juncture; the uppermost line has a series of short vertical engraved lines (Figure 6). On the vessel body are a series of five continuous curvilinear and triangular elements with a central excised triangle and a lower excised triangle. These five elements are separated by five series of short vertical engraved lines at the apex of the curvilinear lines. The outer curvilinear engraved line also has a series of short pendant vertical engraved lines.

PIGMENT USE AND LOCATION ON VESSEL: none

TYPE AND VARIETY (IF KNOWN): Unidentified fine ware 
SITE NAME OR SITE NUMBER: Walter Bell (41SB50)

VESSEL NO.: 1009, Interior of House \#2

VESSEL FORM: Carinated bowl, globular

NON-PLASTICS AND PASTE: grog

RIM AND LIP FORM: Direct rim and rounded lip

CORE COLOR: $\mathrm{G}$ (fired in a reducing environment and cooled in the open air)

INTERIOR SURFACE COLOR: dark grayish-brown; fire clouds on the rim and body

EXTERIOR SURFACE COLOR: dark yellowish-brown; fire clouds on the rim, body, and base

WALL THICKNESS (IN MM): rim, $4.4 \mathrm{~mm}$

INTERIOR SURFACE TREATMENT: smoothed

EXTERIOR SURFACE TREATMENT: smoothed

HEIGHT (IN CM): 5.2

ORIFICE DIAMETER (IN CM): 7.8

DIAMETER AT BOTTOM OF RIM OR NECK (IN CM): 8.3

BASE DIAMETER (IN CM) AND SHAPE OF BASE: 2.5; circular and rounded

ESTIMATED VOLUME (IN LITERS): 0.25

DECORATION (INCLUDING MOTIF AND ELEMENTS WHEN APPARENT): Plain

PIGMENT USE AND LOCATION ON VESSEL: none

TYPE AND VARIETY (IF KNOWN): Unidentified plain ware

SITE NAME OR SITE NUMBER: Walter Bell (41SB50)

VESSEL NO.: 1012 (S189.5 E93.2)

VESSEL FORM: Jar

NON-PLASTICS AND PASTE: grog

RIM AND LIP FORM: Direct rim and rounded lip

CORE COLOR: B (fired and cooled in a reducing environment)

INTERIOR SURFACE COLOR: very dark grayish-brown 
EXTERIOR SURFACE COLOR: black; charred organic residue on the vessel body

WALL THICKNESS (IN MM): rim, $5.6 \mathrm{~mm}$

INTERIOR SURFACE TREATMENT: smoothed

EXTERIOR SURFACE TREATMENT: none

HEIGHT (IN CM): 10.2

ORIFICE DIAMETER (IN CM): 8.9

DIAMETER AT BOTTOM OF RIM OR NECK (IN CM): 8.2

BASE DIAMETER (IN CM) AND SHAPE OF BASE: 5.3; circular and flat

ESTIMATED VOLUME (IN LITERS): 0.54

DECORATION (INCLUDING MOTIF AND ELEMENTS WHEN APPARENT): The rim is decorated with horizontal brushing marks. The vessel body has a continuous series of vertical incised lines that extend from the rim-body juncture to $0.9 \mathrm{~cm}$ above the vessel base.

PIGMENT USE AND LOCATION ON VESSEL: none

TYPE AND VARIETY (IF KNOWN): Unidentified utility ware

SITE NAME OR SITE NUMBER: Walter Bell (41SB50)

VESSEL NO.:-; George M. Fern Collection

VESSEL FORM: Bottle

NON-PLASTICS AND PASTE: grog

RIM AND LIP FORM: N/A

CORE COLOR: $\mathrm{G}$ (fired in a reducing environment and cooled in the open air)

INTERIOR SURFACE COLOR: grayish-brown

EXTERIOR SURFACE COLOR: dark reddish-brown; fire clouds on the body and base; a black resin or organic residue is present on the vessel body

WALL THICKNESS (IN MM): body, $5.6 \mathrm{~mm}$

INTERIOR SURFACE TREATMENT: none

EXTERIOR SURFACE TREATMENT: burnished

HEIGHT (IN CM): N/A 
ORIFICE DIAMETER (IN CM): N/A

DIAMETER AT BOTTOM OF RIM OR NECK (IN CM): $19.7 \mathrm{~cm}$ maximum body diameter

BASE DIAMETER (IN CM) AND SHAPE OF BASE: 9.5; circular and flat

ESTIMATED VOLUME (IN LITERS): N/A

DECORATION (INCLUDING MOTIF AND ELEMENTS WHEN APPARENT): The vessel body has a series of four curvilinear motifs defined by three concentric engraved lines. The innermost curvilinear engraved lines contain an excised circle and a curvilinear excised area (Figure 7). The concentric curvilinear lines are divided by triangle elements with two excised corners.

PIGMENT USE AND LOCATION ON VESSEL: none

TYPE AND VARIETY (IF KNOWN): Unidentified fine ware

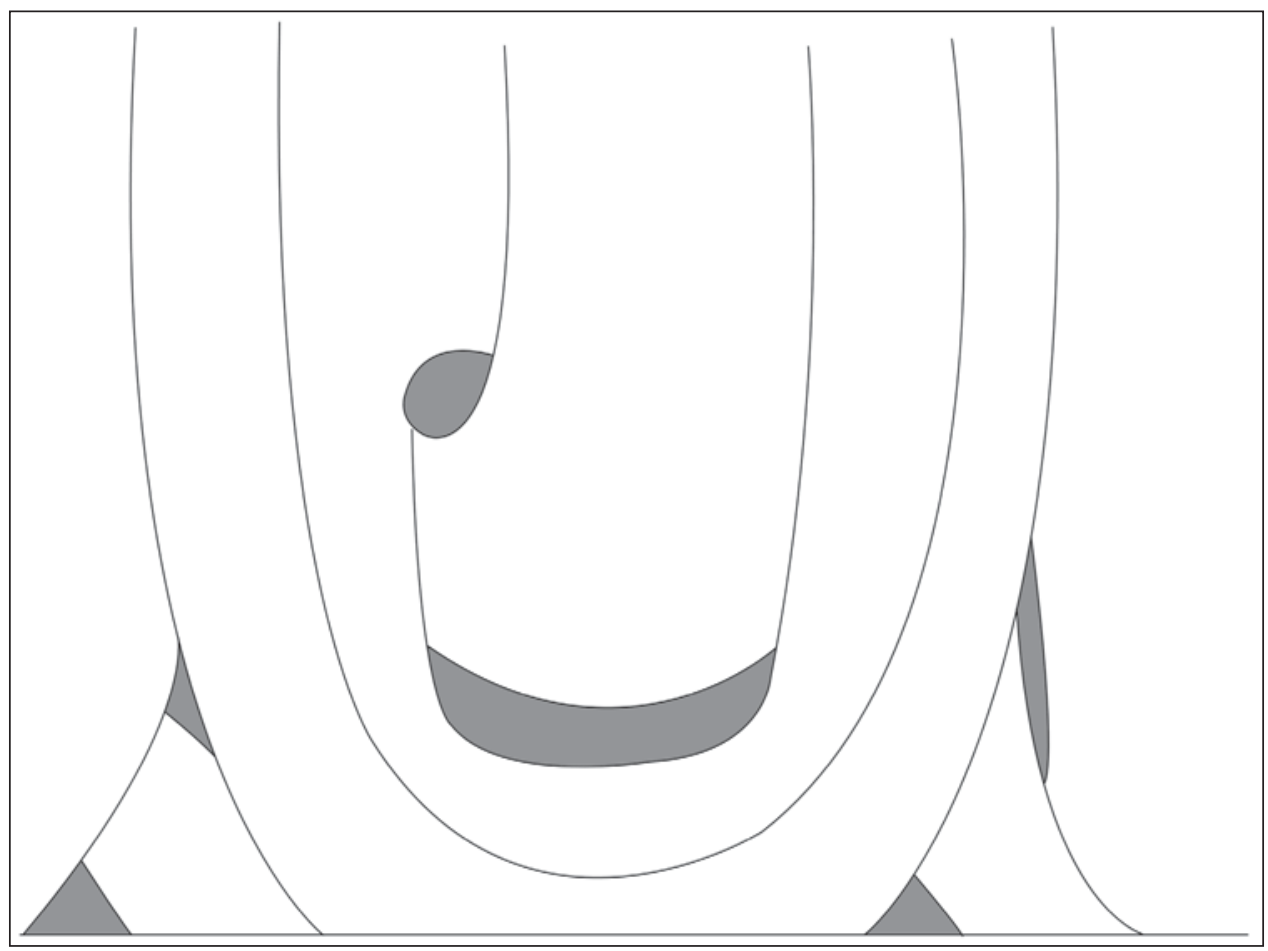

Figure 7. Engraved bottle from the George M. Fern collection from the Walter Bell site (41SB50). 


\section{Bird Point Islands (41SB71)}

The Bird Point Islands site is located on an alluvial terrace on Bear Creek in the southern part of Lake Sam Rayburn (see Figure 1). In 1976, the site was an island (154-160 feet amsl) when the water level was at 154 feet amsl. George M. Fern collected one Caddo ceramic vessel from the site at that time, and subsequently he donated the vessel to TARL. TARL records also indicate that Andy Kyle collected many projectile points from the site between 1946-1986.

SITE NAME OR SITE NUMBER: Bird Point Islands (41SB71)

VESSEL NO.: 1

VESSEL FORM: Jar

NON-PLASTICS AND PASTE: grog

RIM AND LIP FORM: Direct rim and rounded lip

CORE COLOR: $\mathrm{G}$ (fired in a reducing environment and cooled in the open air)

INTERIOR SURFACE COLOR: very dark grayish-brown

EXTERIOR SURFACE COLOR: dark yellowish-brown; fire clouds on the rim and body

WALL THICKNESS (IN MM): rim, $7.0 \mathrm{~mm}$

INTERIOR SURFACE TREATMENT: smoothed

EXTERIOR SURFACE TREATMENT: smoothed on the body

HEIGHT (IN CM): 11.5

ORIFICE DIAMETER (IN CM): 10.4

DIAMETER AT BOTTOM OF RIM OR NECK (IN CM): 10.3

BASE DIAMETER (IN CM) AND SHAPE OF BASE: 8.2; circular and flat

ESTIMATED VOLUME (IN LITERS): 0.72

DECORATION (INCLUDING MOTIF AND ELEMENTS WHEN APPARENT): There are 11 horizontal incised lines on the rim and upper body. Eight horizontal lines are on the rim and the remaining three horizontal incised lines are on the upper vessel body.

PIGMENT USE AND LOCATION ON VESSEL: none

TYPE AND VARIETY (IF KNOWN): Davis Incised 


\section{Sawmill (41SA89)}

The Sawmill site was situated on "a low knoll on the east side of Harvey Creek about a mile above its confluence with the Angelina River" (Jelks 1965:70). Habitation deposits at the site were marked by a ca. 20 cm thick midden overlying a gray to tan sand E-horizon (Jelks 1965:Figure 28).

Excavations of a pit feature (Feature 4) at the Sawmill site recovered a grog-tempered jar with engraved-punctated decorative elements. The one available radiocarbon date from the Sawmill site is from the archaeological deposits in excavation unit N180 E4, coming from charcoal collected on October 15, 1957. The conventional age is $920 \pm 70$ years (Beta-97892). The 2 sigma calibrated age range is A.D. 1035-1081 (Perttula 1998:334). Middlebrook's (1994:29 and Figure 4) consideration of the age of various archaeological sites at Lake Sam Rayburn - particularly the proportion of long-stemmed vs. elbow pipe sherds, the proportion of punctated-incised to brushed sherds, and the overall frequency of brushed ceramic sherds in individual site assemblages - suggests that the Caddo occupation at the Sawmill site likely dates primarily to Middle Caddo period times (i.e., Early Angelina phase).

\section{Vessel}

SITE NAME OR SITE NUMBER: Sawmill (41SA89)

VESSEL NO.: 1, Feature 4

VESSEL FORM: Jar

NON-PLASTICS AND PASTE: grog

RIM AND LIP FORM: Everted rim and rounded lip

CORE COLOR: B (fired and cooled in a reducing environment)

INTERIOR SURFACE COLOR: very dark grayish-brown

EXTERIOR SURFACE COLOR: very dark grayish-brown

WALL THICKNESS (IN MM): rim, $8.0 \mathrm{~mm}$

INTERIOR SURFACE TREATMENT: smoothed

EXTERIOR SURFACE TREATMENT: smoothed

HEIGHT (IN CM): 10.2

ORIFICE DIAMETER (IN CM): 10.8

DIAMETER AT BOTTOM OF RIM OR NECK (IN CM): 10.4

BASE DIAMETER (IN CM) AND SHAPE OF BASE: 10.4; circular and flat

ESTIMATED VOLUME (IN LITERS): 0.66

DECORATION (INCLUDING MOTIF AND ELEMENTS WHEN APPARENT): The lip of the vessel is decorated with diagonal incised lines, and there is a single horizontal engraved line at the base of the rim. 
The vessel body has a series of three repeating linear tool punctated elements (Figure 8). These consist of three concentric circles formed by closely-spaced tool punctations, and these circle elements are separated from each other by tool punctated brackets. Within each bracket are a series of three horizontal punctated bands.

PIGMENT USE AND LOCATION ON VESSEL: none

TYPE AND VARIETY (IF KNOWN): Unidentified fine ware

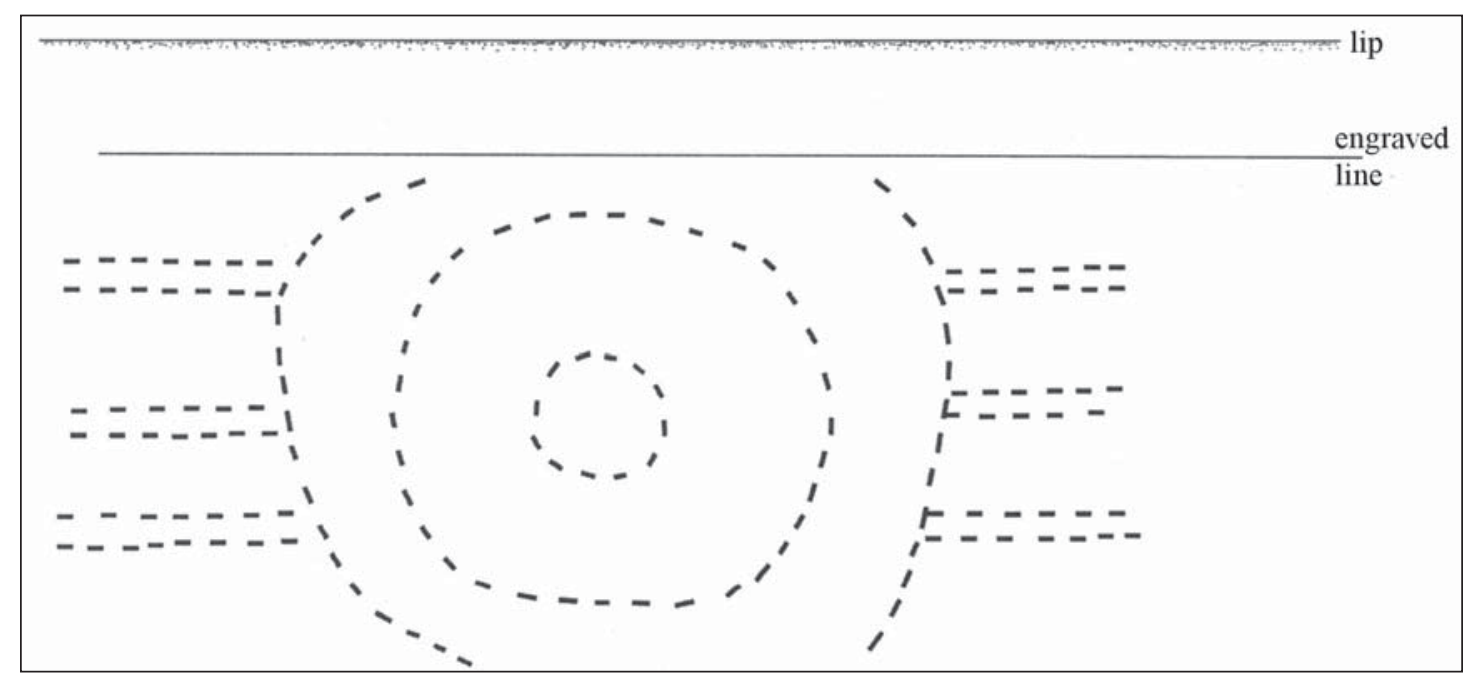

Figure 8. Engraved-punctated jar (No. 1) from Feature 4 at the Sawmill site (41SA89).

\section{Wylie Price (41SA94)}

The Wylie Price site was on a low upland ridge about $1.6 \mathrm{~km}$ east of Attoyac Bayou (Jelks 1965:Figure 33). During the 1957 excavations two ancestral Caddo burial features (Burials 1 and 2) were identified in the western and northern parts of the site.

Burial 1 was an adult female laid in the grave in an extended supine position, facing east, with three ceramic vessels placed near the head and shoulders of the deceased. Also in the burial were 21 blue glass beads that had been placed around the neck of the adult female (Jelks 1965:81, 193). The glass beads remaining in the TARL collections are of simple construction and include one opaque tubular blue bead (6.9 $\mathrm{mm}$ in diameter); two opaque round blue beads $(6.0 \mathrm{~mm}$ in diameter); eight translucent round blue beads ( $5.9 \mathrm{~mm}$ in diameter); and one translucent round dark blue bead (6.3 $\mathrm{mm}$ in diameter). These glass beads are clear evidence that this burial at the Wylie Price site postdates ca. A.D. 1690, when European glass beads begin to be identified in the East Texas Caddo archaeological record (see Perttula 1992; Marceaux 2011).

Burial 2 was an adult buried in a semi-flexed position, with the head facing to the northeast (Jelks 1965:Figure 36). Two complete vessels, one shell-tempered, and a large section of a third vessel had been placed near the left shoulder of the deceased, along with bird bone flageolets (Jelks 1965:82). This burial, if it is associated with the habitation deposits at the site, likely dates to after ca. A.D. 1400, in the late Angelina phase (see Middlebrook 1994:29). 


\section{Vessels}

SITE NAME OR SITE NUMBER: Wylie Price (41SA94)

VESSEL NO.: 170-1, Burial 2

VESSEL FORM: Jar

NON-PLASTICS AND PASTE: shell

RIM AND LIP FORM: Direct rim and exterior folded and flattened lip

CORE COLOR: B (fired and cooled in a reducing environment)

INTERIOR SURFACE COLOR: very dark grayish-brown; charred organic residue on the folded and flattened lip

EXTERIOR SURFACE COLOR: very dark grayish-brown

WALL THICKNESS (IN MM): rim, $4.0 \mathrm{~mm}$; body, $4.2 \mathrm{~mm}$

INTERIOR SURFACE TREATMENT: none

EXTERIOR SURFACE TREATMENT: smoothed

HEIGHT (IN CM): 15.8

ORIFICE DIAMETER (IN CM): 15.2

DIAMETER AT BOTTOM OF RIM OR NECK (IN CM): 14.6

BASE DIAMETER (IN CM) AND SHAPE OF BASE: 7.3; circular and rounded

ESTIMATED VOLUME (IN LITERS): 1.4

DECORATION (INCLUDING MOTIF AND ELEMENTS WHEN APPARENT): The rim panel is defined by upper and lower horizontal incised lines. The panel contains nine vertical incised zones that have a single vertical row of circular punctations (Figure 9).

PIGMENT USE AND LOCATION ON VESSEL: none

TYPE AND VARIETY (IF KNOWN): Unidentified utility ware



Figure 9. Incised-punctated jar (No. 170-1) from Burial 2 at the Wylie Price site (41SA94). 
SITE NAME OR SITE NUMBER: Wylie Price (41SA94)

VESSEL NO.: 171-1, Burial 2

VESSEL FORM: Bowl

NON-PLASTICS AND PASTE: grog

RIM AND LIP FORM: Inverted rim and rounded lip

CORE COLOR: $\mathrm{F}$ (fired in a reducing environment and cooled in the open air)

INTERIOR SURFACE COLOR: reddish-brown; fire clouds on the base

EXTERIOR SURFACE COLOR: reddish-brown; fire clouds on the body

WALL THICKNESS (IN MM): rim, $5.3 \mathrm{~mm}$

INTERIOR SURFACE TREATMENT: smoothed

EXTERIOR SURFACE

TREATMENT: smoothed

HEIGHT (IN CM): 10.0

ORIFICE DIAMETER

(IN CM): 9.8

DIAMETER AT BOTTOM

OF RIM OR NECK (IN CM): N/A

BASE DIAMETER (IN CM)

AND SHAPE OF BASE: 5.0;

circular and convex

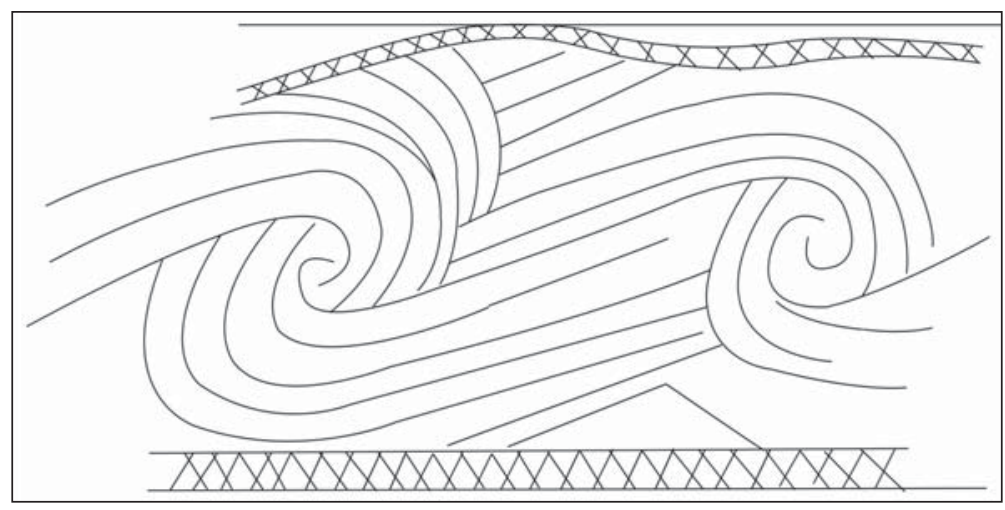

Figure 10. Engraved bowl (No. 171-1) from Burial 2 at the Wylie

ESTIMATED VOLUME

Price site (41SA94).

(IN LITERS): 0.39

DECORATION (INCLUDING MOTIF AND ELEMENTS WHEN APPARENT): The vessel rim and body has multiple engraved scroll motif lines repeated four times around the vessel; the scrolls end in hooked arm elements. Above and below the engraved scrolls are narrow horizontal panels filled with cross-hatched lines (Figure 10).

PIGMENT USE AND LOCATION ON VESSEL: none

TYPE AND VARIETY (IF KNOWN): Unidentified fine ware, cf. Taylor Engraved 
SITE NAME OR SITE NUMBER: Wylie Price (41SA94)

VESSEL NO.: 171-2, Burial 2

VESSEL FORM: Bowl

NON-PLASTICS AND PASTE: grog

RIM AND LIP FORM: Direct rim and rounded lip

CORE COLOR: F (fired in a reducing environment and cooled in the open air)

INTERIOR SURFACE COLOR: dark yellowish-brown

EXTERIOR SURFACE COLOR: dark yellowish-brown; fire clouds on the body and base

WALL THICKNESS (IN MM): rim, 4.6 mm

INTERIOR SURFACE TREATMENT: none

EXTERIOR SURFACE TREATMENT: none

HEIGHT (IN CM): 3.3

ORIFICE DIAMETER (IN CM): 6.6

DIAMETER AT BOTTOM OF RIM OR NECK (IN CM): N/A

BASE DIAMETER (IN CM) AND SHAPE OF BASE: 2.5; circular and rounded

ESTIMATED VOLUME (IN LITERS): 0.09

DECORATION (INCLUDING MOTIF AND ELEMENTS WHEN APPARENT): The vessel rim and body are covered with diagonal brushing marks.

PIGMENT USE AND LOCATION ON VESSEL: none

TYPE AND VARIETY (IF KNOWN): Unidentified utility ware

SITE NAME OR SITE NUMBER: Wylie Price (41SA94)

VESSEL NO.: 1722-1, Burial 1

VESSEL FORM: Jar

NON-PLASTICS AND PASTE: grog

RIM AND LIP FORM: Everted rim and rounded lip

CORE COLOR: B (fired and cooled in a reducing environment) 
INTERIOR SURFACE COLOR: very dark grayish-brown

EXTERIOR SURFACE COLOR: very dark grayish-brown; fire clouds on the rim and body; charred organic residue on the vessel body

WALL THICKNESS (IN MM): rim, $5.1 \mathrm{~mm}$

INTERIOR SURFACE TREATMENT: smoothed

EXTERIOR SURFACE TREATMENT: none

HEIGHT (IN CM): 11.8

ORIFICE DIAMETER (IN CM): 7.6

DIAMETER AT BOTTOM OF RIM OR NECK (IN CM): 6.9

BASE DIAMETER (IN CM) AND SHAPE OF BASE: 3.7; circular and flat

ESTIMATED VOLUME (IN LITERS): 0.54

DECORATION (INCLUDING MOTIF AND ELEMENTS WHEN APPARENT): Vertical incised lines on the rim and body that extend to within $0.5 \mathrm{~cm}$ of the vessel base.

PIGMENT USE AND LOCATION ON VESSEL: none

TYPE AND VARIETY (IF KNOWN): Unidentified utility ware

SITE NAME OR SITE NUMBER: Wylie Price (41SA94)

VESSEL NO.: 1726-2; Burial 1

VESSEL FORM: Jar

NON-PLASTICS AND PASTE: grog

RIM AND LIP FORM: Everted rim and rounded lip

CORE COLOR: B (fired and cooled in a reducing environment)

INTERIOR SURFACE COLOR: dark grayish-brown

EXTERIOR SURFACE COLOR: dark grayish-brown; fire clouds on the rim

WALL THICKNESS (IN MM): rim, $5.2 \mathrm{~mm}$

INTERIOR SURFACE TREATMENT: smoothed on the rim

EXTERIOR SURFACE TREATMENT: none

HEIGHT (IN CM): 9.0 
ORIFICE DIAMETER (IN CM): 8.3

DIAMETER AT BOTTOM OF RIM OR NECK (IN CM): 7.7

BASE DIAMETER (IN CM) AND SHAPE OF BASE: 5.1; circular and flat

ESTIMATED VOLUME (IN LITERS): 0.45

DECORATION (INCLUDING MOTIF AND ELEMENTS WHEN APPARENT): The vessel is decorated with a continuous series of broad vertical incised lines that extend from the rim to $0.7 \mathrm{~cm}$ above the vessel base.

PIGMENT USE AND LOCATION ON VESSEL: none

TYPE AND VARIETY (IF KNOWN): Unidentified utility ware; cf. Belcher Ridged

Vessel 171-3 in Burial 2 at the Wylie Price site is represented by only a section of the vessel. It is the body section of a Broaddus Brushed jar that has vertical brushing marks. The jar is grog-tempered, and it was fired and cooled in an oxidizing environment. The body walls are $6.7 \mathrm{~mm}$ thick, smoothed on the interior vessel surface, and there are fire clouds on the body section.

\section{Blount (41SA123)}

The Blount site was located on an alluvial knoll alongside Spear Creek, a small tributary to Attoyac Bayou (Jelks 1965:98). Excavations in 1960 and 1962 took place in an extensive midden deposit that encountered portions of a Caddo structure, a hearth, and a pit feature (Jelks 1965:102). The provenience of the one vessel in the TARL collections from the Blount site is not stated in Jelks (1965), suggesting it may have been obtained through a donation by a collector.

The one available radiocarbon date from the Blount site is from N495 E560, 0.5-1.0 foot level. The conventional age is $460 \pm 70$ years B.P. (Beta-97893). At 2 sigma, the calibrated age range is A.D. 14051615 (Perttula 1998:334), which appears to be at least several hundred years too young given the frequency of long-stemmed pipe sherds at the site and the low proportion of punctated-incised to brushed sherds (see Middlebrook 1994:29); these suggest the site dates to the early Angelina phase, or Middle Caddo period.

\section{Vessels}

SITE NAME OR SITE NUMBER: Blount (41SA123)

VESSEL NO.: 1

VESSEL FORM: Four-cornered bottle

NON-PLASTICS AND PASTE: bone

RIM AND LIP FORM: N/A

CORE COLOR: B (fired and cooled in a reducing environment)

INTERIOR SURFACE COLOR: grayish-brown

EXTERIOR SURFACE COLOR: grayish-brown 
WALL THICKNESS (IN MM): body, $8.7 \mathrm{~mm}$

INTERIOR SURFACE TREATMENT: none

EXTERIOR SURFACE TREATMENT: burnished

HEIGHT (IN CM): N/A

ORIFICE DIAMETER (IN CM): N/A

DIAMETER AT BOTTOM OF RIM OR NECK (IN CM): N/A

BASE DIAMETER (IN CM) AND SHAPE OF BASE: N/A

ESTIMATED VOLUME (IN LITERS): N/A

DECORATION (INCLUDING MOTIF AND ELEMENTS WHEN APPARENT): The vessel body has a curvilinear engraved scroll motif with a central circle element (Figure 11). Upper and lower scroll fill zones have four or five negative $\mathrm{S}$-shaped elements outlined by hatched and cross-hatched triangular and bracket-shaped zones, as well as a concentric circle element.

PIGMENT USE AND LOCATION ON VESSEL: none

TYPE AND VARIETY (IF KNOWN): Unidentified fine ware



Figure 11. Decorative elements on engraved bottle from the Blount site (41SA123). 


\section{SUMMARY AND CONCLUSIONS}

During the archaeological investigations conducted by The University of Texas at Austin in the late 1950s-early 1960s at Lake Sam Rayburn in the Angelina River and Attoyac Bayou basins in East Texas (Jelks 1965, 2006, 2014), 21 ancestral Caddo ceramic vessels were recovered from five different sites: Walter Bell (41SB50, n=12 vessels), Bird Point Islands (41SB71, $\mathrm{n}=1$ vessel), Sawmill (41SA89, $\mathrm{n}=1$ vessel), Wylie Price (41SA94, $n=6$ vessels), and Blount (41SA123, $n=1$ vessel). The likely ages of the vessels from the site are Early Caddo period (ca. A.D. 1000-1200, n=1 vessel from Bird Point Islands); Middle Caddo period (ca. A.D. 1200-1400, early Angelina phase, $n=2$ vessels from the Sawmill and Blount sites); Late Caddo period (ca. A.D. 1400-1680, late Angelina phase, $\mathrm{n}=15$ vessels from the Walter Bell and Wylie Price sites); and Historic Caddo (post ca. A.D. 1680, $\mathrm{n}=3$ vessels from the Wylie Price site).

The one Early Caddo period vessel is a grog-tempered Davis Incised jar with horizontal incised lines on the rim and body of the vessel. The two Middle Caddo period vessels are a grog-tempered jar and a bone-tempered bottle. The lip of the jar from the Sawmill site is decorated with diagonal incised lines, and there is a single horizontal engraved line at the base of the rim. The vessel body has a series of three repeating linear tool punctated elements. These consist of three concentric circles formed by closely-spaced tool punctations, and these circle elements are separated from each other by tool punctated brackets. Within each bracket are a series of three horizontal punctated bands. The four-cornered bottle from the Blount site is decorated on the body with a curvilinear engraved scroll motif with a central circle element. Upper and lower scroll fill zones have four or five negative S-shaped elements outlined by hatched and cross-hatched triangular and bracket-shaped zones, as well as a concentric circle element.

The Late Caddo vessels from the Walter Bell and Wylie Price site include seven jars, four carinated bowls, two bowls, and two bottles. Eighty percent are tempered with grog, 13 percent are tempered with bone, and one incised-punctated jar is tempered with shell (6.7 percent); this vessel was likely made by a Caddo potter in a Northwest Louisiana community (see Perttula et al. 2012). Two of the carinated bowls in these assemblages are plain, four are fine ware vessels (a carinated bowl, two bottles, and a bowl), and the remaining nine vessels are utility ware jars $(n=8)$ and bowls $(n=1)$. The fine ware vessels have engraved motifs, and one of the bone-tempered carinated bowls is a Glassell Engraved type (see Suhm and Jelks 1962:Plate 27). The bowl, from the Wylie Price site, has engraved scrolls that end in hooked arm elements and comparables favorably to Taylor Engraved, and the two bottles from the Walter Bell site have distinctive engraved designs:

(a) on the first bottle there are three horizontal engraved lines below the neck-body juncture; the uppermost line has a series of short vertical engraved lines. On the vessel body are a series of five continuous curvilinear and triangular elements with a central excised triangle and a lower excised triangle. These five elements are separated by five series of short vertical engraved lines at the apex of the curvilinear lines. The outer curvilinear engraved line also has a series of short pendant vertical engraved lines; and

(b) the vessel body of the second bottle has a series of four curvilinear motifs defined by three concentric engraved lines. The innermost curvilinear engraved lines contain an excised circle and a curvilinear excised area. The concentric curvilinear lines are divided by triangle elements with two excised corners.

The utility ware vessels in Late Caddo period contexts at the Walter Bell and Wylie Price sites include jars that resemble Karnack Brushed-Incised (with vertical and diagonal brushing marks on the vessel body) and Belcher Ridged (with vertical incised lines on the rim and body), and there are two jars with horizontal brushed rims and vertical incised bodies. A bowl from Burial 2 at the Wylie Price site has been decorated with diagonal brushing marks. Two other jars from the Walter Bell site have tool punctated rows on the vessel rim and either diagonal brushing marks or vertical to diagonal opposed incised lines on the body. A 
utility ware jar from Burial 3 at the Walter Bell site is decorated on the rim with an incised triangle filled with tool punctations; there are two upper and lower incised triangles around the vessel rim. Between the incised triangles are areas filled with diagonal brushing marks that are overlain with diagonal incised lines pitched in opposite directions. The one shell-tempered utility ware jar from the Wylie Price site, in Burial 2, has a rim panel defined by upper and lower horizontal incised lines. The panel contains nine vertical incised zones that have a single vertical row of circular punctations.

The three ceramic vessels from an Historic Period context at the Wylie Price site are all grog-tempered jars. Two have vertical incised lines on the rim and vessel body, one of which compares favorably to a Belcher Ridged vessel, and the third vessel is a Broaddus Brushed jar with vertical brushing marks on the rim and body.

The 21 vessels described herein document at least 700 years of use at these Lake Sam Rayburn archaeological sites by Caddo peoples. The majority of the vessels are from Late Caddo period (i.e., late Angelina phase) burials and features, which is likely the period in which the Caddo occupation peaked in this part of the Angelina and Attoyac stream basins in East Texas.

\section{ACKNOWLEDGMENTS}

We thank Jonathan Jarvis of the Texas Archeological Research Laboratory at The University of Texas at Austin for access to the vessels from the Lake Sam Rayburn sites for study. Sandra Hannum and Lance Trask prepared the figures in this article.

\section{REFERENCES CITED}

Jelks, E. B.

1965 The Archeology of McGee Bend Reservoir, Texas. Ph.D. dissertation, Department of Anthropology, The University of Texas at Austin.

2006 Reminiscences of Archaeology in Texas: 1947-1968. Plains Anthropologist 51(200):597-614.

2014 Archaeological Salvage at Texas Reservoir Construction Projects: 1945-1969. In Dam Projects and the Growth of American Archaeology: The River Basin Surveys and the Interagency Archeological Salvage Program, edited by K. M. Banks and J. Czaplicki, pp. 85-94. Left Coast Press, Inc., Walnut Creek.

Marceaux, P. S.

2011 The Archaeology and Ethnohistory of the Hasinai Caddo: Material Culture and the Course of European Contact. Ph.D. dissertation, Department of Anthropology, The University of Texas at Austin.

McClurkan, B. B., W. T. Field, and J. N. Woodall

1966 Excavations in Toledo Bend Reservoir, 1964-65. Papers of the Texas Archeological Salvage Project No. 8. Texas Archeological Salvage Project, The University of Texas at Austin.

Middlebrook, T. A.

1994 An Update of Archaeological Investigations at the Tyson Site. Journal of Northeast Texas Archaeology $3: 1-36$.

1997 The Caddoan Occupation of the Attoyac and Angelina River Basins in the Middle Caddoan Period. Journal of Northeast Texas Archaeology 10:36-40.

Perttula, T. K.

1992 "The Caddo Nation": Archaeological and Ethnohistoric Perspectives. University of Texas Press, Austin.

1998 A Compendium of Radiocarbon and Oxidizable Carbon Ratio Dates from Archaeological Sites in East Texas, with a Discussion of the Age and Dating of Select Components and Phases. Radiocarbon 39(3):305-342. 
Perttula, T. K. and R. Z. Selden Jr.

2014 Ancestral Caddo Ceramics in East Texas. Journal of Northeast Texas Archaeology 48:9-58.

Perttula, T. K. and M. Walters

2015 Woodland and Caddo Period Sites at Toledo Bend Reservoir, Northwest Louisiana and East Texas. Journal of Northeast Texas Archaeology 56, 19-124.

Perttula, T. K., R. Cast, B. Gonzalez, and B. Nelson

2009 Documentation of Unassociated and Culturally Unidentifiable Funerary Objects in the U.S. Army Corps of Engineers, Fort Worth District Collections Housed at the Texas Archeological Research Laboratory at the University of Texas at Austin. Special Publication No. 13. Friends of Northeast Texas Archaeology, Pittsburg and Austin.

Perttula, T. K., M. B. Trubitt, and J. S. Girard

2012 The Use of Shell-tempered Pottery in the Caddo Area of the Southeastern United States. Southeastern Archaeology 30(2):242-267.

Story, D. A.

1990 Cultural History of the Native Americans. In The Archeology and Bioarcheology of the Gulf Coastal Plain, by D. A. Story, J. A Guy, B. A. Burnett, M. D. Freeman, J. C. Rose, D. G. Steele, B. W. Olive, and K. J. Reinhard, pp. 163-366. Research Series No. 38. 2 Vols. Arkansas Archeological Survey, Fayetteville.

Suhm, D. A. and E. B. Jelks (editors)

1962 Handbook of Texas Archeology: Type Descriptions. Special Publication No. 1, Texas Archeological Society, and Bulletin No. 4, Texas Memorial Museum, Austin. Reprinted in 2009, Gustav's Library, Davenport, Iowa.

Woodall, J. N.

1969 Archeological Excavations in the Toledo Bend Reservoir, 1966. Contributions in Anthropology No. 3. Department of Anthropology, Southern Methodist University, Dallas. 